\title{
Representation of Selected Aspects of World War II and Their Influence on Personality Transformation in the Book Painted Bird by Jerzy Kosiński
}

\author{
Milan Mašát \\ Palacký University Olomouc, Faculty of Education, Department of Czech Language and Literature, Žižkovo náměstí 5, 77140 \\ Olomouc, Czech Republic
}

Received March 19, 2021; Revised April 27, 2021; Accepted May 23, 2021

\section{Cite This Paper in the following Citation Styles}

(a): [1] Milan Mašát, "Representation of Selected Aspects of World War II and Their Influence on Personality Transformation in the Book Painted Bird by Jerzy Kosinski," Linguistics and Literature Studies, Vol. 9, No. 3, pp. 84 - 90, 2021. DOI: 10.13189/lls.2021.090302.

(b): Milan Mašát (2021). Representation of Selected Aspects of World War II and Their Influence on Personality Transformation in the Book Painted Bird by Jerzy Kosiński. Linguistics and Literature Studies, 9(3), 84 - 90. DOI: 10.13189/lls.2021.090302.

Copyright $\bigcirc 2021$ by authors, all rights reserved. Authors agree that this article remains permanently open access under the terms of the Creative Commons Attribution License 4.0 International License

\begin{abstract}
The main goal of the paper is to answer the question How are selected aspects of World War II represented in the artistic narrative The Painted Bird by Jerzy Kosinski? After reading the novel, the analysis examined the main lines of depiction of the events happened in World War II, focusing on those that are, in my opinion, key to the interpretation of the novel and to create parallels between artistic literary representation and reality of World War II. After the introduction, in which I presented the circumstances that accompanied the publication of the book The Painted Bird in the United States of America and then in other countries (discussions and disputes were mainly based on depictions of brutality, which, however, was an integral part of life during World War II), I focused on selected aspect implemented into the narrative. I have divided them into five groups: 1) A Futile Struggle for Life, 2) Christians versus Jews, 3) I'm One of You: Looting of the Kalmyks, 4) The Habits of the Villagers and 5) Implementation of the Ideas of Communism. The analysis showed that selected aspects of World War II, focusing on the integration of a multilateral view of selected events of a defined historical phase, are represented in the Kosiński's narrative mainly through a certain influence of the external environment on the formation of the boy's personality. The first metamorphosis is guided by the devaluation of its ethical and moral values with the main goal: to survive. This effort
\end{abstract}

permeates the entire artistic narrative and is most significantly depicted in the futile struggle for the life of a painted bird in the environment of individuals of its kind, which is a parallel to the boy's life among other people. The second transformation of his personality takes place during the rage of the Kalmyks in one of the villages, during which he realizes his resemblance to these people and in a way seeks to explain the transformation of his moral values based on external resemblance to them. A certain "correction" of his not very fault due to a distorted personality profile is thematized in a meeting with a Russian soldier who is trying to acquaint the boy with communist ideas. Based on the presentation of selected aspects that were part of the Second World War and their representation in the analyzed artistic narrative, I believe that The Painted Bird should become an integral part of compulsory school reading.

Keywords The Painted Bird, Jerzy Kosiński, Holocaust, Shoah, Multilateral View

\section{Introduction}

Today, the events of the Second World War are becoming increasingly important, especially by the 
warnings that this historical phase provides us with: for example, warnings about the social impact of racism, anti-Semitism, xenophobia or various explicit and implicit persecution practices against selected individuals or groups (compare [5] or [8] or [21]). Primarily, the Shoah events are perceived as experiencing one line of World War II events from the point of view of Jews. This approach is quite understandable, because during this war, at least six million people were identified in the Nazi extermination camps, whom the Nazi regime called members of the Jewish people. In the shadow of the Jewish Holocaust (within the article, I perceive the terms Shoah and Holocaust synonymously - see [3]) is the fate of other groups of people who have also been identified as undesirable by representatives of National Socialism, such as other religious groups, homosexuals, Roma, and the like [13].

From a historical and social point of view - with a certain degree of generalization - the participants in World War II are viewed schematically. On the one hand, members of the National Socialist Party and, for the most part, Germans, who, according to various sources, accepted Nazism and its theses, some fully identified with them and were tolerated by most of the nations, are described as "evil". In general, those whom against the statutes of Nazism were directed, as well as the armies of the states, thanks to which the Second World War ended in victory for the anti-Nazi alliance, are described as "good" (compare [7]).

It is the differentiation of the participants in the Second World War (voluntary, i.e., active, and involuntary, i.e., passive) that leads to a certain black-and-white view of one line of events of the Second World War as a whole. It is with this view that the pupils and students, who are acquainted with this historical epoch in various educational fields, are also familiar with it. I am of the opinion that in addition to the educational field of History, in which the presentation of these events has its justified place, actors of institutional education should be acquainted with warnings arising from Shoah events in other school subjects even within the literary component of native language teaching.

As part of the paper, I will try to present selected aspects in the publication by Jerzy Kosiński, which can be used (not only) to present a multilateral view of Shoah events through literary texts on the example of the publication The Painted Bird $([9 ; 10 ; 11 ; 12]$ - publication of the book in the Czech language). As part of the analysis of The Painted Bird narrative, I notice aspects that relate the life destiny of a boy who is trying to survive the hardships of World War II, with the general meaning of selected events for contemporary society connoted to the warnings of a particular phase of the twentieth century (see above).

Recently, several articles about selected publication have been written in connotation with various phenomena that are thematized in it. Prušková [15 p. 259] deals with "non-pragmatic language that, when dealing with deliberately chosen texts about acts of violence, leads to productive aesthetic disturbance", on the basis of five artistic narratives, in the center of which is the issue of the Holocaust, including The Painted Bird.

Carpenter [2 p. 7] deals with the application of Emmanuel Levinas' Ethical Demand for the Stranger in the Kosiński narrative, concluding that "The Painted Bird (and other of Kosiński's works) using Levinasian themes. Even though The Painted Bird has been treated under the auspice of Freudian, Heideggerian and Nietzschean critiques, these ways of reading fail to notice the ethical demand of non-indifference."

Savchyn [16] was devoted to the representation of contemporary Ukrainian space in connection with the narrative statement about the totalitarian political establishment in the article Totalitarian Discourse in translation: The Painted Birds by Jerzy Kosinsski in Ukraininian Cultural Space. Bohn [1] uses Kosiński's narrative to illustrate Belarus' post-war development. "The result is an illustration of the metamorphoses that took place in the transitional region of Central and Eastern Europe in the process of Soviet modernization." [1 p. 32]

About social relations in connotation with modeling and transformation of the boy's personality, the main protagonist of the Kosiński's novel, is dealt with Conner [4].

Shpylova-Saeed [18 p. 169] "seeks to explore how silence informs the narrative that balances between the inner space of the narrator - a monologue - and the outside events in which he appears to be involved. In this discussion, silence is viewed as an active force for engaging with memory and as a stage for transformation to an audible story that shapes a traumatic experience."

Before starting, the analysis has determined the main research question: How are selected lines and aspects of World War II represented in the artistic narrative Painted Bird? After reading the novel, I excerpted the main lines of representation of the events of World War II in the analyzed novel, focusing on those that are, in my opinion, crucial for the interpretation of the novel and for drawing parallels between artistic literary representation and reality.

I believe that an important part of Kosiński's book is the discussions that began after the publication of this artistic narrative. In the following chapter, I summarize the main ideas that accompanied The Painted Bird after its publication, in comparison with the views of those who lived in the United States and the so-called Eastern Bloc, which was under the influence of the communist regime at the time of the novel.

\section{Discussion after the Publication of the Painted Bird}

Jerzy Kosiński's work caused numerous discussions 
and controversies immediately after its publication. Many reviewers and the general public have criticized the author that The Painted Bird narrative fulfilled his desire to write a book full of brutality and violence: "They claimed that I used the horrors of war to give free rein to my own, very strange imagination." "[12 p. 257] (compare [19]) The author further notes: "The purpose of the novel I decided to write was to explore (...) the language of brutality and the contrasting new language of anxiety and fear, which was a natural reaction to the raw reality." [12 p. 248] Many controversies have been caused by the writer's failure to revise reviewers' claims that it is an autobiographical novel. He decided to remain silent based on his belief that "the life of the novel must remain independent." [12 p. 250] Shawver [17 pp. 292-293] refutes the integration of the autobiography into the text of The Painted Bird: "Kosiński's real experiences were completely different from those he described in The Painted Bird. Liwinkopf's family (Jerzy Kosiński was born in Lodž in Poland as Józef Lewinkopf; note from the author of the article) was relatively wealthy and survived the war because the local villagers helped them, even though they took the risks themselves. At one point, Jerzy was taken over by a Catholic family and obtained a fake birth certificate."

In Poland, the native country of the author of The Painted Bird, and in countries that are called Eastern Bloc, ideological campaigns were conducted against Kosiński based on taking certain passages of the novel out of context and based on changes in their sequence and built on their misinterpretations. "Most of the rejecting Eastern European critics focused on the alleged specificity of the novel. (...) My critics have accused The Painted Bird of being an offensive, abusive documentary about how people whose identities are easy to establish during World War II are easy to establish." [12 p. 251] Other reviewers criticized the writers for "ridiculing the folk traditions of their home provinces or distorting local customs, tarnishing the character of the villagers, and strengthening propaganda." [12 pp. 251-252] "Critical voices grew as soon as [Kosiński's] books were published in his native Poland after the fall of communism in 1989. Professionally and personally, he never recovered from accusations and public shame." [17 p. 293]

The basis of the controversies against the book, and even the essence of the personal attacks on the author, was the depiction of a view of one line of World War II different from what was accepted in the consensus. The protagonist of the story, which can be characterized as $a$ book road movie, is the Roma, which is one of the fundamental aspects of another (multilateral) view of the events of World War II. During his travels in the Nazi-occupied country, the boy meets various people who

\footnotetext{
${ }^{1}$ All citations from The Painted Bird, which I present in the article, are based on translation of the Czech-language 4th edition of the publication.
}

live in complete opposition to how the boy lived before his parents sent him from a large city to a distant village in the fall of 1939, where he was to survive the war with a foster mother.

During his various meetings, the numerous characters of the people are depicted, and the many folklore and other customs of the backward countryside are depicted. The discrepancies between the boy's life so far and a certain cruelty of the villagers change the boy's character and his perception of life gradually. He becomes a man whose main goal is to survive in all circumstances. This moment shows the power of external influences on the formation of man, especially the child, and the change of one's own worldview. This situation gradually turns against the boy in relation to his surroundings, even though behind this personality transformation are the villagers, whom he met as part of his forced wandering. Perhaps that is why he finds his happiness in the Russian Liberation Army, in which there is a certain order, in which there are clearly defined boundaries, and which has a clearly defined goal.

Based on the analysis, I will try to demonstrate how selected lines of The Painted Bird could have influenced the outlined (non)acceptance of this publication in the countries of the so-called Eastern Bloc.

\section{A Futile Struggle for Life}

The line of the futile struggle for life, combined with the effort to win over the stronger, is set at the beginning of the story. "One day, as the pigeon was trying to make friends with chickens and hens, as usual, a small black shape broke away from the clouds. The hens screamed to the barn and chicken coop. The black ball fell like a stone among a fleeing flock. Only the pigeon had nowhere to hide. Before he had time to spread his wings, a powerful bird nailed him to the ground with his sharp curved beak and began to peck at him. Pigeon's feathers were stained with blood." [12 p. 18] The symbolism of the encounter between the weaker and the stronger, the effort to defend his life against a more powerful force is a kind of memento of the relationship between a Romani boy and the occupying Nazi troops whose power denied his separation from his family, his subsequent loss of contact the boy's forced wandering around country homesteads.

Kosiński develops the symbol of birds fighting in vain, which has already been indicated at the very beginning of the narrative, when a boy meets a man named Lech. The release of colored birds between their cousins symbolizes the events of the Shoah. One group of people murdered others, because they somehow slipped out, because they were different, or because they looked different. "Then he went into the woods. There he pulled the painted birds out of the cage and ordered me to take it in my hand and squeeze it gently. The bird began to chirp, drawing a flock 
of birds of the same species, which flew nervously overhead. (...) The painted birds flew from one end of the flock to the other, trying in vain to convince their cousins that he was one of them. (....) After a short while, the multicolored creature lost its place in the sky and fell to the ground." [12 p. 61] Painted birds are attacked by other birds of the same species, pushed out of the flock, and killed. The fate of a different creature is identical with the fate of people who were destined to be exterminated by the Nazi leaders. At first, these people did not believe the news that spread from Germany after Hitler became chancellor, they did not believe that people would be able to commit the atrocities they learned about from other people. This aspect can also be perceived from another point of view, not only as a campaign by those who are described in the consensus as "evil" against the "good"; it can also be purges within these groups. In the context of The Painted Bird, it can be said that the fate of a boy who was different from the inhabitants of the village in which the boy had always resided for some time. The villagers, controlled by their habits, ideas of life are influenced by their mundane desires, viewed the boy as something unwanted, as something that had no place in their community because he did not grow up in it because (initially) he did not accept generally accepted views in it and ideas. Thanks to his ability to adapt to the nature of the villagers, which was reflected in his inner transformation, he survived. He realized in time that he was different for them and that it was necessary to accept their ideas about life and interiorize some of their qualities.

Attacks on painted birds can also be seen at the level of trying to deal with people who have adopted a certain opinion. I am thinking, for example, of the efforts of some Germans to somehow put an end to those who have adopted National Socialist ideas. Of course, these efforts could not come to a successful end (perhaps at the very beginning of the promotion of these ideas). However, the struggle of a stigmatized bird can be seen as a possible effort to spread a certain political belief across the general public.

A fighting bird which is seen as different by his flock, is not aware of his difference. The motive of the bird is crucial in Kosiński's book. Inspired by Aristophanes' satirical play Birds, he decided to make these animals the main motive and symbol that predetermines the outcome of the publication.

The effort to preserve life related to the loss of something or someone close, symbolized by animals, is also developed on the example of a squirrel: "The little animal weakened, his jumps getting shorter and slower until the boys finally caught him. However, the squirrel continued to bravely wrestle and bite. The boys then bent over her and poured some liquid on her from a can." [12 pp. 19-20] The death of a squirrel means, on the one hand, a desire for life; on the other hand, a certain predisposition to death. An animal, like a boy, can defend itself against numerical and force superiority only within limited possibilities. Despite the initial equal struggle, behind which there was enough strength, over time he becomes exhausted and, in a sense, reconciled to his destiny. It is no coincidence that the boy is an eyewitness to the animal's futile struggle. The squirrel's struggle is a picture of his own fight, at the beginning of which he was full of strength and determination, but which gradually changed the boy's perception of himself and his surroundings. The initial desire for life turned into a desire not to die.

In my opinion, the aspect of the struggle for life forms the central narrative line of the Kosiński novel. At the primary level, it manifests itself in the boy's desire to live, to which several analogies can be found in the novel, such as the squirrel's struggle for life, but especially the fight of a painted bird with members of the same social (animal) group. Carpenter's [2] postulated relationship between Levinas' Ethical Demand for the Stranger and his representation in the Kosiński's novel is applicable in this line of narrative. At the same time, the boy's personality is transformed by external factors that devalue his moral values (see [4]).

\section{Christians versus Jews}

In the novel, Kosiński does not avoid the controversial relationship between the majority group of Christian-oriented people and Jews (see [6] or [20]). After all, the tense relationship between Christians and Jews has its roots in the life of Christ. The author expresses the attitude of the majority public to the group of people was most affected by Nazi extermination policy through the views of villagers after hearing the stories of men who worked near the extermination camp: "They deserved it long ago, as soon as they crucified Christ. God never forgot them. If he has neglected their sins so far, it does not mean that he has forgiven them. Now the Lord used the German as his tool to administer justice. Jews were to be denied the right to natural death. They must have perished in the flames and suffered hellish torment here, on earth. They were justly punished for the shameless crimes of their ancestors, for refuting the only true faith, for ruthlessly killing Christian children and for drinking their blood." [12 pp. 105-106] The question of the coexistence of Christians and Jews and the relationship between the majority public and the Germans falls, in our view, within the scope of a multilateral view of defined events (see [14]).

The majority public is unwilling to accept the fact that it has not always been truly convinced of the monstrosity of the Nazi extermination plan, that it has not always made full use of its - albeit limited - possibilities to help Jews. I believe that the relationship between the two groups during World War II generally points to the inability or unwillingness of some people to accept the differing views 
or differences of others as such. In The Painted Bird, that difference is symbolized in the relationship between the boy and the somewhat limited villagers, who at least partially accept it (albeit only for personal gain) after the boy's life beliefs are transformed and the boy-child metamorphosis longs for protection. Others in a boy-man who pursues hard for his goal, that is, to survive, even at the expense of others.

\section{I'm One of You: Looting of the Kalmyks}

The multilateral view used in the Kosiński's book also represents the looting of the Kalmyks, a group used by the German occupiers as their vanguard before entering various villages, towns, or areas. Kosiński relates a certain fear that the villagers had for the boy, with his resemblance to a terrible group that broke into the village. The boy visually identifies with the Kalmyks and relates similar features to a certain form of revenge, which the Kalmykian group performs for him, under a weak and against the superiority of a helpless child. "I looked at them and for a moment I felt great pride and satisfaction. These proud riders were black-haired, black-eyed, and as dark-skinned as I was. They differed from other people in the village as night and day. The fair-haired villagers were afraid of the dark Kalmyks, and their arrival drove them almost insane." [12 pp. 182-183] After the boy sees the rage of the Kalmyks associated with the rape of all the living, the burning of houses, the burning of people alive, and the like, despite his similar features, he begins to distance himself from them, at the same time explaining his destiny through their actions.

A certain awareness of one's own resemblance to those who do evil to essentially innocent villagers is a certain culmination of the transformation of the boy's personality influenced by a change in his ethical values. To depict the impulses that led to the boy's insight, Kosiński uses the naturalistic descriptions of the Kalmyks' rage, which formed one of the main planes of remorse for this artistic narrative, forming language and its various means and layers (see [15]).

\section{The Habits of the Villagers}

The publication mentions a considerable number of customs, superstitions, and legends that the rural population believed in. The boy listened to many stories and then sifted his view of the world based on these stories. Many explanations have the character of myths, the villagers used them to explain phenomena which, in their opinion, had no other (substantiated, scientific) interpretation. An example is the explanation of the rainbow: “. ... the rainbow is a long, arched stem, hollow like straw. At one end, it is submerged in a river or lake and drinks water from it, which it then distributes evenly throughout the region. Along with the water, it also draws out fish and other animals, which is why we find the same species of fish in lakes, ponds and rivers that are far apart." [12 p. 112] Among the superstitions that have been translated among the villagers is that the number of teeth someone counts will make your life shorter by so many years. This superstition was behind many of the boy's negative experiences of wandering the villages.

In the period and space where a given section of the boy's life takes place, the mythological explanation of phenomena for which the inhabitants of the villages had no other explanation was widely used and, in a way, mythological prism for certain aspects of life shaped and influenced the daily life of villagers.

\section{Implementation of the Ideas of Communism}

One of the reasons why the book was banned in the so-called Eastern Bloc and why negative propaganda was waged against it and which affected Jerzy Kosiński's life and the lives of his loved ones, was the integration of pro-communist ideas into the narrative. Although this thesis could a priori testify to the opposite approach of critics from the so-called Eastern Bloc, the opposite is true. Do not forget that the book was published in the United States of America and over time spread to democratic Western European countries. It is this fact, combined with the depiction of the ideas of communism from the boy's point of view, the "race board", that leads to the fact that the true meaning of the text is reversed, that it sounds exactly the opposite of how it is written. The boy receives communist ideas from the Soviet soldier Gavrila, who returns the meaning of life and puts order in it. The boy, who left his parents at the age of six, who has never been systematically educated, thus uncritically accepts all of Gavrila's views, and thanks to this soldier, who is very close to him, he identifies with them. In the thoughts of communism, the boy finds an explanation of his situation, an explanation of why his frequent prayers were not answered. "I have learned from him that the order of the world has nothing to do with God and that God has nothing to do with the world. The reason was quite simple. God did not exist." [12 p. 194]

The moment Gavrila introduces the boy to the ideas about a person's social status, which determines his possible rise on the social ladder, the boy realizes that due to his origin he could not get to higher social ranks in socialist society. At this point, he finds his hope in the military, even though the ideas of partisanship and the supremacy of social status over everything else emerge from his ideas. "Did this mean that, just as the villagers I lived among were bothered by my black hair and eyes, my 
social background could be to my detriment in the new life among the Soviet people? The position of a man on the military rankings was determined by his rank and function in the regiment. The old member of the party had to follow exactly the orders of his commander, who did not even have to be a member of the party. (...) The commander could punish an officer who was a member of the party, and the party could then further degrade the officer and bring him down to the lower rung of the military hierarchy." [12 pp. 200-201]

The citation explicitly shows that the boy's personality was changed again due to external factors. It is no longer a metamorphosis in the line of instinctually in the plane of survival, but a change in his perception of the world in connection with political opinion. His perception of Gavrila's postulated ideas is interpreted by the boy, tabula rasa, on the basis of his experience and cognitive maturity so far, which leads to a certain change in the message of ideas that the Russian soldier passes on to the boy. It was the integration of pro-communist ideas with the opposite message to the political representation of the countries in which this ideology was applied at the time of the publication of Kosiński's work that formed one of the lines why this work of art was not published at all in those countries and why the author had to face threats of secret agents of communist countries. A certain opposing message of the ideas is also underlined by the boy's silence (the boy stopped communicating with the world after being thrown into the pit by the inhabitants of a village), so Gavrila cannot correct his acquisition of those ideas and they are presented to the reader with their interpretation through the boy's thoughts.

\section{Conclusions}

The discussions and controversies that accompanied The Painted Bird immediately after its release stemmed mainly from depictions of brutality, which, however, was an integral part of life during World War II. The naturalistic depiction of selected aspects of the lives of children who were forced by circumstances to take care of themselves, using all available means, demonstrates the futility and horror of war as such.

Through the interpretation of selected aspects, I tried to show that in The Painted Bird one line of World War II events is drawn from a multilateral perspective, i.e., from a different perspective than how the Shoah or the Holocaust is generally depicted: the boy himself, the protagonist of Kosiński's story, is Roma.

The main narrative level of the story is the fight of a painted bird for members of his group. This motive is depicted in detail in the story of the boy's encounter with Lech, who captures the birds, then paints them and, after being released back among his species, observes with interest how other, non-stigmatized, birds try to drive the intruding "alien" out of their flock. It regularly ends with the death of a stained individual. This aspect permeates the whole story. The painted bird is the boy himself, who tries to integrate among the villagers through which he goes through in his quest to survive. Ludmila, who is driven by her lust, makes all the men who care about her happy. The painted bird is Labina's husband, who gets rich and whose wealth is worth his life. It can be said that almost every character who enters the boy's life is a painted bird in some way trying to find its place in society, where many of them fail and their life journey ends in death. The main painted bird - a boy - finds his place in the Soviet army, where he clings to Gavrila, who introduces him to the ideas of communism. Thanks to communist theses, he always realizes that, within every political establishment, there are painted birds that are forced to fight hard for their place. The fundamental message of the publication can also be evidenced by the fact that the narrative does not mention the boy's name, which underlines the general message of the book on the level of each of use's struggle for a place in this world.

The main research question before starting the analysis was determined How are selected lines and aspects of World War II represented in the artistic narrative Painted Birds? The analysis showed that selected aspects of World War II, focusing on the integration of a multilateral view of selected events of a defined historical stage, are represented in the Kosiński's book mainly through a certain influence of the external environment on the formation of the boy's personality. The first metamorphosis is guided by the devaluation of its ethical and moral values with the main goal: to survive. This effort permeates the entire artistic narrative and is most significantly depicted in the futile struggle for the life of a painted bird in the environment of individuals of its kind, which is a parallel to the boy's life among other people. The second transformation of the hero's personality takes place during the rage of the Kalmyks in one of the villages, during which he realizes his resemblance to these people and in a way seeks to explain the transformation of his moral values based on external resemblance to them. A certain "correction" of his not very fault due to a distorted personality profile is thematized in a meeting with a Russian soldier who is trying to acquaint the boy with communist ideas.

Other aspects of World War II that are discussed in the publication include, for example, the outline of the habits of the villagers in the area where this road-movie takes place, and which to a large extent also shape the boy's perception of the world.

The Painted Bird has been included in compulsory school reading for several years after their release in the United States of America. I hope that after the successful Czech film adaptation (see [22]) of the Kosiński's novel, which led the general public to read it, The Painted Bird will become part of the if-not mandatory, then at least 
recommended reading in Czech educational institutions. If someone argues that this book is unsuitable for pupils and students to read because of the naturalistic depiction of many events, then there is only one answer: Wasn't World War II like that? And in connection with the message of the book: Aren't we all painted birds?

\section{Acknowledgements}

This contribution was supported by IGA project IGA_PdF_2021_001_Multilateral Representation of Shoah Events in the Literature of Palacký University Olomouc.

\section{REFERENCES}

[1] Bohn T. M., Bagpipe Players and Painted Birds: Some Reflections on Writing the History of the People in the Marshes from a German Perspective, Journal of Belarusian Studies, vol. 10, no. 1, pp. 32-43, 2020. DOI: $10.30965 / 20526512-12350001$.

[2] Carpenter Ch. D., A Re-Appropriation of Jerzy Kosinski's Moral Universe in Light of Emmanuel Levinas' Ethical Demand for the Stranger, Dissertation, The University of Texas at Dallas, 2017, pp. 297, https://utd-ir.tdl.org/bitstrea $\mathrm{m} /$ handle/10735.1/5962/ETD-5608-035-CARPENTER-814 9-20.pdf?sequence=5\&isAllowed=y (accessed April 24, 2021).

[3] Carrier P., Messinger, T., Eckhardt, F., The International Status of Education about the Holocaust - A Global Mapping of Textbooks and Curricula, 1st ed, UNESCO, 2015, pp. 235.

[4] Conner M., The Anti-Human Condition: Violence, Identity, and Coming-of-Age in The Painted Bird, Undergraduate Student Research Awards, 2017, pp. 16, https://digitalcommons.trinity.edu/infolit_usra/35 (accessed April 24, 2021).

[5] Due Enstad J., Antisemitic Violence in Europe, 2005-2015. Exposure and Perpetrators in France, UK, Germany, Sweden, Norway, Denmark, and Russia, University of Oslo, 2017, pp. 31, https://www.hlsenteret.no/aktuelt/publikasjone r/digitale-hefter/antisemittisk-vold-i-europa_engelsk_endeli g-versjon.pdf (accessed April 24, 2021).

[6] Epp, E. J., The Jews and the Jewish Community in Oxyrhynchus: Socio-Religious Context for the New Testament Papyri, Perspectives on New Testament Textual Criticism, vol. 2, no. 2020, pp. 3-40, 2020. DOI: 10.1163/9789004442337_002.

[7] Hébert V., The Problem of Human Rights after the Holocaust, A Companion to the Holocaust, 2020, pp. 553-575. DOI: 10.1002/9781118970492.ch31.

[8] Jacoby J., Forgetting the Holocaust, AishHaTorah,
https://www.aish.com/jw/s/Forgetting-the-Holocaust.html (accessed Feb. 4, 2021).

[9] Kosiński. J. N., The Painted Bird, 1st ed, Argo, 1995, pp. 215.

[10] Kosiński. J. N., The Painted Bird, 2nd ed, Argo, 2011, pp. 215.

[11] Kosiński. J. N., The Painted Bird, 3rd ed, Argo, 2017, pp. 254.

[12] Kosiński. J. N., The Painted Bird, 4th ed, Argo, 2019, pp. 262.

[13] Nadler R. A. M., Was the Holocaust Only Against Jews? AishHaTorah, https://www.aish.com/ho/i/Was_the_Holocaust_Only_Agai nst_Jews.html (accessed Jan. 24, 2021).

[14] Overy R. J., Dictators, 1st ed, Beta-Dobrovský, 2006, pp 695.

[15] Prušková Z., The Holocaust - the Border of Pragmatic Language, Poznańskie Studia Slawistyczne, vol. 2017, no. 12, pp. 259-270, 2017. DOI: 10.14746/pss.2017.12.17.

[16] Savchyn V., Totalitarian Discource in Translation: The Painted Bird by Jerzy Kosiński in Ukrainian Cultural Space, ТЕЗИ reporting scientific conference teaching staff (Faculty of Foreign Languages), (February 4-5, 2020) 2021, pp. 158 , https://d1wqtxts1xzle7.cloudfront.net/65677851/Tezy_zvitn oi_naukovoi_konferentsii_profesors_ko_vykladats_koho_sk ladu_fakul_tetu_inozemnykh_mov_za_2020_rik.pdf?16132 20121=\&response-content-disposition=inline\%3B+filename \%3D65677851.pdf \&Expires $=1619345983 \&$ Signature $=$ HIJp fgW-OUnf-4z 7J0bLQA4G3OsjkrRkCvKGOy2Rp0-yLLN MqzE3NkId6w6AhaGzZhIMrq J8wHy MJx0ovSFs6sj5W pLwmMDsJ38F 1CZucG4TdXFXJYQX86BwudYjbuOkP4 BH38BWKbjm5jheExP90TRyBFZPAzVtB7CTbu1HTIBH cb4liYHRS-yXJ5Y7nKg2q9 qz-59ElZo1xAgnqVdrjI7xfr WHuEQW4 9EObyuT4EQEdyfzjYnzJ0oEZ3GcLcIkTr125 Z9ApSR6n4YE7xtTt5BR3xSHbPrzvVKi7Am-ZZ5skEv Sr DvhS56GpqcPsxA1t5WJz1918hDZy9A_\&Key-Pair-Id=A PKAJLOHF5GGSLRBV4ZA\#page $=159$ (accessed April 24 2021).

[17] Shawver K., Henry, 1st ed, Euromedia Group, 2019, pp. 317.

[18] Shpylova-Saeed N., Speaking Silence in Jerzy Kosiński's Painted Bird, Pennsylvania Literary Journal, vol. 11, no. 1, pp. 169-184, 2019. https://search.proquest.com/openview/a 0be5dcb9d2e3d314cbaab22321e6564/1?pq-origsite=gschola r\&cbl=1356369 (accessed April 24, 2021).

[19] Sloan J. P., Jerzy Kosinski: A Biography, 1st ed, Dutton Adult, 1996, pp. 512.

[20] Stroup Ch., Introduction. Jews and Christians in the Polis, The Christians Who Became Jews, Yale University Press, 2020, pp. 1-16. DOI: 10.12987/9780300252187-003.

[21] Tamminen T., Himmler and His Finnish Buddha, 1st ed, CPress, 2020, pp. 349.

[22] The Painted Birds movie website: https://nabarveneptace.cz/ (accessed April 24, 2021). 